\title{
Optimalisasi Dan Simulasi Terhadap Perkembangan Kognitif Anak Usia Dini
}

\author{
Yusnita \\ PIAUD, STAI Auliaurrasyidin Tembilahan
}

\begin{abstract}
ABSTRAK
Perkembangan kognitif adalah salah satu aspek perkembangan peserta didik yang berkaitan dengan pegetahun yaitu proses psikologis yang berkaitan yaitu bagaimana individu untuk mempelajari lingkungan. Mengembangkan kognitif peserta didik adalah merupakan tugas seorang guru yang harus diterapkan dalam proses pembelajaran. Metode yang digunakan adalah analisis deskriptif library untuk menggambarkanUpaya Optimalisasi dan Simulasi terhadap perkembangan kognitif anak usia dini. Piaget berpendapat bahwa terdapat empat perkembangan kognitif, salah satunya adalah tahap praoperasional.Tahapan ini merupakan tahap perkembangan anak usia dini dimana dalam keadaan usia emas ini harus dioptimalkan dengan pendidikan sehingga anak akan berkembang secara optimal.Siswa pada usia ini menggunakan bentuk bentuk simbol dengan cara yang makin canggih. Guru dapat membantu mereka dengan pendekatan keterampilan proses dan memberi penekatan konsep-konsep. Karena siswa dalam usia ini dalam tahap proses penyempurnaan penalaran hendaknya kita jangan menganggap mereka berfikir seperti kita. Hendaknya kita harus tetap waspada dalam menginterprestasikan pendapat didalam kelas, dengan memberikan kesempatan mengungkapkan pendapat.
\end{abstract}

Kata Kunci: Optimalisasi dan simulasi AUD, Perkembangan Kognitif

\begin{abstract}
Cognitive development is one of students' development that emphases on knowledge -psychological process -to discover surroundings. Developing students' knowledge is a teacher work. This is an analytical library research that is to show the optimization and simulation on development of the early childhoods' cognitive. Piaget asserts four cognitive development which one of is preoperational stage. The stage is the early childhood development where they are in a golden age should be optimized through the education. At this stage, they learn through the use of symbols with the latest approach in learning. Teacher can help over the skills process and giving concepts for the students' refinement of reasoning, so we should be aware of giving interpretation in class by giving them chances to express their ideas.
\end{abstract}

Keywords: Early childhood optimization and simulation, ognitive development

Corresponding Author:

Yusnita

Email address: yusnita.j2prime18@gmail.com 


\section{PENDAHULUAN}

Usia dini merupakan periode masa emas bagi perkembangan anak dimana tahap perkembangan otak pada anak usia dini menempati posisi yang paling vital yakni meliputi $80 \%$ perkembangan otak anak. Periode emas ini sekaligus merupakan periode kritis bagi perkembangan anak, karena pada periode ini sangat berpengaruh terhadap perkembangan pada periode berikutnya hingga masa dewasanya. Periode ini hanya datang sekali dan tidak dapat ditunda kehadirannya, sehingga apabila terlewat berarti habislah peluangnya. Oleh karena itu, masa-masa usia dini harus dimanfaatkan semaksimal mungkin dengan memberikan pendidikan yang sesuai dengan perkembangannya.

Menurut Soemiarti bahwa Taman Kanak-kanak merupakan salah satu bentuk pendidikan anak usia dini yang menyediakan berbagai program belajar melalui bermain untuk membantu anak mencapai pertumbuhan dan perkembangan diri yang optimal. Hal ini sesuai dengan keputusan Menteri Pendidikan dan Kebudayaan Nomor 0486/U/1992 Bab 1 Pasal 2 ayat (1) yang menyatakan bahwa Pendidikan Taman Kanak-kanak merupakan wadah untuk membantu pertumbuhan dan perkembangan jasmani dan rohani anak didik sesuai dengan sifatsifat alami anak (Patmonodewo, 2003, hal. 44).

Ada beberapa aspek perkembangan yang harus dicapai anak dalam kegiatan pelaksanaan program di Taman Kanak-kanak, karena anak usia dini memiliki karakteristik yang khas baik secara fisik, psikis, sosial, moral, dan sebagainya. Aspek-aspek tersebut yaitu perkembangan fisik/motorik, perkembangan kognitif, perkembangan bahasa, perkembangan sosial emosional, perkembangan moral dan nilai agama, dan perkembangan seni. Menurut Hibana (2002, hal. 35) bahwa anak usia 4-5 tahun memiliki karakteristik antara lain; berkait dengan perkembangan fisik, anak sangat aktif melakukan kegiatan. Perkembangan bahasa juga semakin baik, anak sudah mampu memahami pembicaraan orang lain dan mampu mengungkapkan pikirannya. Perkembangan kognitif (daya pikir) sangat pesat, menunjukkan dengan rasa ingin tahu akan anak yang luar biasa terhadap lingkungan sekitarnya. Bentuk permainan anak masih bersifat individu, bukan permainan-permainan sosial, walaupun aktivitas bermain dilakukan anak secara bersama.

Para ahli psikologi memandang proses perubahan yang dapat dilihat kearah yang lebih baik. Dalam hal ini banyak faktor yang mempengaruhi dalam proses belajar diantaranya adalah proses psikologis anak salah satunya kecerdasan. kecerdasan ini erat hubunganya dengan perkembangan kognitif peserta didik.

Dalam praktik proses belajar mengajar tentu mengacu pada teori belajar yaitu pandangan satu dasar dalam proses belajar. Dalam hal ini terdapat berbagai 
teori yaitu : teori kontruktivisme, teori humanisme, teori behaviotistik, dan teori kognitivisme. Itulah diantaranya teori dalam proses belajar mengajar.

Dari berbagai teori di atas salah satunya adalah teori kognitivisme salah satu aliran yang mempunyai pengaruh yang sangat besar dalam praktik belajar disekolah. Aliran ini memberikan kontribusi terhadap unsur unsur kognitif atau mental dalam proses belajar. Menurut aliran psikologi kognitif belajar merupakan sebuah proses mental yang aktif untuk mencapai, mengangat, dan menggunakan pengetahuan. Sehingga prilaku yang tampak pada manusia tidak dapat diukur dan diamati tanpa melibatkan proses mental seperti motivasi, kesengajaan, keyakinan, dan lain sebagainya (Baharuddinn \& Wahyuni, 2010, hal. 87).

Berawal dari pandangan teori kognitif diatas maka perlu bagi seorang guru untuk mengetahui tentang perkembangan kognitif anak usia dini karena dalam proses belajar telah jelas melibatkan proses mental dalam diri peserta didik. Guru harus dapat membuat motivasi dan dorongan kepada peserta didik agar supaya mereka merasa benar benar menerima sesuai yang menjadi kebutuhannya. Perkembangan kognitif dari peserta didik ini sangat penting untuk diperhatikan.

Dalam perkembangan peserta didik usia dini harus perlu diperhatikan perkembangan kogntif nya karena pada tahap ini anak pada usia emas yang perlu untuk terus tercapai perkembangannya. Pada hal ini guru memiliki peran yang sangat penting dalam upaya optimalisasi dari perkembangan kognitif siswa pada usia dini.

\section{METODE PENELITIAN}

Metode yang digunakan adalah Analisis deskriptif library. Dalam melakukan kegiatan analisa dekriptif yaitu penulis menggambarkan tentang Upaya Optimalisasi dan Simulasi terhadap perkembangan kognitif anak usia dini.

\section{HASIL DAN PEMBAHASAN}

\section{Pengertian Perkembangan Kognitif}

Perkembnagan kognitif adalah salah satu aspek perkembanngan peserta didik yang berkaitan dengan pegetahun yaitu proses psikologis yang berkaitan yaitu bagaimana individu untuk mempelajari lingkungan. Mengembangkan kognitif peserta didik adalah merupakan tugas seorang guru yang harus diterapkan dalam proses pembelajaran (Desmita, 2009, hal. 97).

Intelek adalah kemampuan jiwa atau psikis yang relatif menetap dalam proses berfikir, untuk membuat huungan tanggapan, serta kemampuan memahami, menganalisis, mengevaluasi. Intelek berfungsi dalam proses pembentukan konsep yang dilakukan melalui pengindraan, pengamatan, tanggapan, ingantan, dan berpikir (Ingriwati, 2009).

Bermain dapat memenuhi kebutuhan anak untuk secara aktif terlibat dengan lingkungan, untuk bermain dan bekerja dalam menghasilkan suatu karya, serta 
untuk memenuhi tugas-tugas perkembangan kognitif lainnya. Selama bermain, anak menerima pengalaman baru, memanipulasi bahan dan alat, berinteraksi dengan orang lain dan mulai merasakan dunia mereka. Bermain menyediakan kerangka kerja untuk anak untuk mengembangkan pemahaman tentang diri mereka sendiri, orang lain, dan lingkungan. Bermain adalah awalan dari semua fungsi kognitif selanjutnya, oleh karenanya bermain sangat diperlukan dalam kehidupan anakanak.

Proses kognitif meliputi perubahan dalam pikiran, inteligensi, dan bahasa manusia. Contoh proses kognitif terjadi dalam mengenali benda-benda pada bayi, menggabung kalimat, menguasai kata, mengingat puisi, mengerjakan soal-soal matematika, membayangkan sesuatu yang akan terjadi, menemukan jawaban sebab akibat, atau memahami sesuatu yang tersirat dalam sebuah peristiwa.

Dalam permendikbud 137 perkembangan kognitif adalah :

a. Menunjukkan aktivitas yang bersifat eksploratif dan menyelidik (seperti: apa yang terjadi ketika air ditumpahkan)

b. Memecahkan masalah sederhana dalam kehidupan sehari-hari dengan cara yang fleksibel dan diterima sosial

c. Menerapkan pengetahuan atau pengalaman dalam konteks yang baru

d. Menunjukkan sikap kreatif dalam menyelesaikan masalah (ide, gagasan di luar kebiasaan)

Teori perkembangan kognitif Piaget salah satu teori yang men- jelaskan bagaimana anak beradaptasi dan menginterpretasikan objek dan kejadian-kejadian sekitarnya. Anak-anak mempelajari ciri-ciri dan fungsi dari objek-objek seperti mainan, perabot, dan makanan serta objek-objek sosial seperti diri, orangtua dan teman. Anak-anak juga mempelajari cara mengelompokan objek-objek untuk mengetahui persamaan-persamaan dan perbedaan-perbedaannya, untuk memahami penyebab terjadinya perubahan dalam objek-objek dan perisiwa- peristiwa dan untuk membentuk perkiraan tentang objek dan peristiwa tersebut

Skema adalah struktur kognitif yang merupakan proses atau cara mengorganisir dan merespons berbagai pengalaman. Skema adalah suatu pola sistematis dari tindakan, perilaku, pikiran, dan strategi pemecahan masalah yang memberikan suatu kerangka pemikiran dalam meng- hadapi berbagai tantangan dan jenis situasi. Adaptasi adalah istilah bagi struktur fungsional kognitif yang digunakan oleh Piaget untuk menunjukan pentingnya pola hubungan individu dengan lingkungannya dalam proses perkembangan kognitif. Menurut Piaget, adaptasi ini terdiri dari dua proses yang saling melengkapi, yaitu asimilasi dan akomodasi.

Asimilasi dari sudut biologis adalah integrasi antara elemen- elemen eksternal (dari luar) terhadap struktur yang sudah lengkap pada organisme. Asimilasi kognitif meliputi objek eksternal menjadi struktur pengetahuan internal. Proses asimilasi ini didasarkan atas kenyataan bahwa setiap saat manusia selalu 
mengasimilasikan informasi-informasi yang sampai kepadanya, kemudian informasi- informasi tersebut dikelompokan ke dalam istilah-istilah yang sebelumnya telah mereka ketahui. Dengan kata lain asimilasi adalah proses mencocokkan praktik kepada teori. Proses asimilasi dapat diilustrasikan sebagai berikut:

Akomodasi adalah kemampuan menciptakan langkah baru atau memperbarui atau menggabungkan berbagai istilah lama untuk menghadapi tantangan baru. Akomodasi kognitif berarti mengubah struktur kognitif yang telah dimiliki sebelumnya untuk disesuaikan dengan objek stimulus eksternal. Jadi kalau pada asimilasi terjadi perubahan pada objeknya, maka pada akomodasi perubahan terjadi pada subjeknya, sehingga manusia dapat menyesuaiakan diri dengan objek yang ada di luar dirinya. Struktur kognitif yang sudah ada dalam diri seseorang mengalami perubahan supaya sesuai dengan rangsangan- rangsangan objeknya. Dengan kata lain akomodasi adalah proses mencocokkan teori ke dalam praktik.

Piaget mengemukakan bahwa setiap organisme yang ingin meng- adakan adaptasi (penyesuaian) dengan lingkungannya harus mencapai keseimbangan (equilibrium ), yaitu antara aktivitas individu terhadap lingkungan (asimilasi) dan aktivitas lingkungan terhadap individu (akomodasi). Agar terjadi ekuilibrasi antara individu dengan lingkungan, maka peristiwa-peristiwa asimilasi dan akomodasi harus terjadi secara terpadu, bersama-sama dan saling melengkapi.

Konsep yang mendasari pengertian nerupakan kemampuan menangkap sifat, arti atua keterangan, sesuatu yang memunyai gambaran yang jelas tentang hal tersebut (Hurlock, 1990). Pengertian didasarkan pada konsep yang terbentuk melalui pengindraan secra langsung merupakan perpaduan atau penggabungan berbagai hal yang disatukan dengan berbagai unsur, objek, situasi, sehingga menyatu dalam satu konsep.

Fungsi intelektual berkaitan erat dengan intelegensi yang dinyatakan sebgai kecerdasan merupakan kapasitas atau kecakapan potensial yang terdiri atau general faktor, spesial faktor, common faktor. Dalam hal ini kemampuan kognitif atau intelektual adalah yang berhubungan dengan intelegensi seseorang.

Perkembanngan kognitif adalah tahap-tahap perkembangan manusia secara psikis dalam perubahan kemapuan berfikir atau intelektual dalam ajaran islam perkembangan kognitif dibagi menjadi empat tahap yaitu Allah menjadikan lemah, kuat lemah kembali, dan berubah yaitu yang tertera dalam surat Ar-ruum ayat 54(Hasan, 2006, hal. 135).

Piaget mengemukakan bahwa konep dan prinsip tentang perkembangan anak diantaranya:

\section{a. Anak adalah belajar yang aktif}

Anak bukan hanya mengobservasi atau mengingat apa yang mereka lihat secara pasif, sebaliknya mereka juga memiliki rasa ingin tahu terhadap dunia mereka. 


\section{b. Anak mengorganisasikan dari apa yang mereka pelajari dari pengalaman}

Anak tidak hanya mengumpulkan dari apa yng mereka pelajari dari fakta fakta yanga terpisah menjadi satu kesatuan sebaliknya anak juga membangun pandangan menyeluruh tentang gabaiman dunia bergerak.

c. Anak menyesuai kan diri dengan lingkungan melalui asimilasi dan akomodasi

Asimilasi ketika seorang anak memasukan pengetahuan yang baru dan akomodasi terjadi ketika anak menyesuaikan dengan informasi yang baru.

\section{d. Peningkatan anak dalam pemikiran yang lebih kompleks}

Dalam hal ini anak dapat memecahkan konflik, mampu memahami kejadian kejadian yang sebelumnya membingungkan serta keseimbangan pemikirannya. Dari hal ini berawal dari proses asimilasi anak dalam proses penerimaan informasi dan fakta fakta yang ada dan juga proses akomodasi terhadap penyesuaian imformasi yang baru tersebut. Proses ini sangat penting untuk diperhaikan karena pda hal ini anak sudah mulai berusaha untuk terus mengembangan kan pola pokirnya.

\section{Tahap-Tahap Perkembangan Kognitif}

Tahap-tahap pemikiran seorang menurut jean piaget berkembang melalui serangkaian pemikirakan dari masa bayi hingga masa dewasa yaitu fase sensiromotor, fase praoperasional, fase operasional kongkrit, dan fase formal (Yusuf, 2012, hal. 4).

\section{a. Tahap Sensiromotor}

Pada tahap ini adalah usia antara 0 sampai 2 tahun artinya anak dapat berinteraksi melalui aktivitas sensiromotor dimulai dengan anak dilahirkan dengan gerak-gerakan repleks yang dimiliki anak sejak lahir.

Tahap sensori motoris ditandai dengan karakteristik menonjol sebagai berikut: 1) Segala tindakannya masih bersifat naluriah. 2) Aktifitas pengalaman didasarkan terutama pada pengalaman indera. 3) Individu baru mampu melihat dan meresap pengalaman, tetapi belum untuk mengkategorikan pengalaman itu. 4)Individu mulai belajar menangani obyek-obyek konkrit melalui skema-skema sensori-motorisnya.

Sebagai upaya lebih memperjelas karakteristik tahap sensoris motoris ini, maka Piaget merinci lagi tahap sensori motoris ke dalam enam fase dan setiap fase memiliki karakteristik tersendiri sebagai berikut;

a) Fase pertama (0-1 bulan) memiliki karakteristik sebagai berikut: 1) Individu mampu bereaksi secara refleks 2) Individu mampu menggerak-gerakkan anggota badan meskipun belum terkoordinir 3) Individu mampu mengasimilasi dan mengakomodasikan berbagai pesan yang diterima dari lingkungannya. 
b) Fase kedua (1-4 bulan) memilki karakteristik bahwa individu mampu memperluas skema yang dimilikinya berdasarkan heriditas.

c) Fase ketiga ( 4 - 8 bulan) memiliki karakteristik bahwa individu mulai dapat memahami hubungan antara perlakuannya terhadap benda dengan akibat yang terjadi pada benda itu Fase keempat (8-12 bulan) memiliki karakteristik sebagai berikut:

1) Individu mampu memahami bahwa benda tetap ada meskipun untuk sementara waktu hilang dan akan muncul lagi di waktu lain

2) Individu mulai mampu mencoba-coba sesuatu

3) Individu mampu menentukan tujuan kegiatan tanpa tergantung kepada orang tua.

d) Fase kelima (12-18 bulan), memiliki karakteristik sebagai berikut: 1) Individu mulai mampu untuk meniru 2) Individu mampu untuk melakukan berbagai percobaan terhadap lingkungannya secara lebih lancar

e) Fase keenam (18-24 bulan) memiliki karakteristik sebagai berikut: 1) Individu mulai mampu untuk mengingat dan berfikir 2) Individu mampu untuk berfikir dengan menggunakan simbol- simbol bahasa sederhana 3) Individu mampu berfikir untuk memecahkan masalah sederhana sesuai dengan tingkat perkembangnnya. 4) Individu mampu memahami diri sendiri sebagai individu yang sedang berkembang

\section{b. Fase Praoperasional}

Dalam fase ini adalah usia antara 2 sampai 7 tahun. Fase praoperasioanal adalah dimulai menyadari pemahamannya tentang benda-benda disekitarnya fase ini adalah fase permulaan bagi anak-anak membangun kemampuannya menyusun pikirannya oleh sebab itu cara berfikir anak pada fase ini belum stabil dan terorganisasi dengan baik.

Tahap pra operasional ditandai dengan karakteristik menonjol sebagai berikut:

1) Individu telah mengkombinasikan dan mentransformasikan berbagai informasi

2) Individu telah mampu mengemukakan alasan-alasan dalam menyatakan ide-ide

3) Individu telah mengerti adanya hubungan sebab akibat dalam suatu pristiwa konkrit, meskipun logika hubungan sebab akibat belum tepat.

4) Cara berfikir individu bersifat egosentris yang ditandai oleh tingkahlaku berikut ini: a) Berfikir imanigatif b) Berbahasa egosentris c) Memiliki aku yang tinggi d) Menampakkan dorongan ingintahu yang tinggi e) Perkembangan bahasa mulai pesat

\section{c. Fase Operasional Kongkrit}

Dalam fase ini anak antara 7 sampai 11 tahun pada tahap ini anak sudah bisa melakukan berbagai macam tugas melalui tiga macam operasi yaitu, negasi 
kemampuan anak untuk memahami proses yang teradi diantara kejadian dan memahami hubungan antara keduanya, resprokasi kemampuan melihat hubungan timbal balik, identitas kemampuan mengenali benda benda yang ada. Dalam tahap ini anak sudah dapat berfikir secara kongkrit dalam memahami sesuatu sebagaimana kenyataannya, memahami sesuatu melalui pengalamanya.

Tahap operasional konkrit ini ditandai dengan karakteristik menonjol bahwa segala sesuatu dipahami sebagaimana yang tampak saja atau sebagaimana kenyataan yang mereka alami. Jadi, cara berfikir individu belum menangkap yang abstrak meskipun cara berfikirnya sudah nampak sistematis dan logis. Dalam memahami konsep, individu sangat terikat kepada proses mengalami sendiri. Artinya mudah memahami konsep kalau pengertian konsep itu dapat diamati atau melakukan sesuatu yang berkaitan dengan konsep tersebut. (Asrori, 2003, hal. 39-42)

Dengan demikian, karakteristik-karakteristik yang dikemukakan di atas dapat dijadikan pedoman bagi orang tua/guru dalam melihat perkembangan kognisi anak dari tahap-ketahap pada setiap perkembangannya. Sehingga dapat diketahui apakah anak tersebut sudah memiliki kemampuan kognitif yang optimal atau belum? Untuk menghindari keterlambatan perkembangan anak tersebut, maka orang tua/guru dapat melakukan berbagai kegiatan stimulasi atau perangsangan pada anak agar mencapai tingkat perkembangan yang wajar.

Menurut Piaget setidaknya ada empat kemampuan dasar yang perlu dirangsang pada anak pra sekolah, ialah:

1) Kemampuan transformasi: yaitu perubahan bentuk dapat dikenalkan pada anak pra sekolah lewat eksperimen sederhana, misalnya meniupkan balon, menuangkan air kedalam gelas yang berbeda, merubah benda lunak menjadi berbagai bentuk, dan lain-lain.

2) Kemampuan reversibility; yaitu cara berfikir alternatif atau bolak balik, misalnya dengan sebuah gambar anak diajak untuk mencari jalan keluar dari sebuah jalan yang banyak liku-likunya, atau anak diminta mengurutkan angka dari kecil ke yang lebih besar dan kemudian kembali dari angka yang besar ke yang lebih kecil.

3) Kemampuan klasifikasi; yaitu anak diajak untuk melakukan klasifikasi berdasarkan jenis, bentuk, warna, ukuran dan lain-lain, kemampuan klasifikasi ini ada tiga ialah klasifikasi tunggal, ganda dan jamak. Tunggal misalnya hanya berdasarkan satu aspek misalnya warna saja. Ganda sudah dua aspek, misalnya warna dan bentuk, sedangkan jamak sudah dengan banyak aspek, misalnya warna, bentuk dan bahan dasarnya. Hal penting dari latihan ini adalah pada kemampuan berfikir logis.

4) Kemampuan hubungan asimetris: yaitu tidak semua klasifikasi didasarkan atas kesamaan, tetapi juga bisa atas dasar perbedaan. Misalnya besar, kecil, panjang, pendek, tinggi dan rendah, anak dapat dilatih menyususn balok 
secara urut dari yang besar sampai yang kecil atau dari yang panjang sampai kepada yang pendek (Yusuf, 2005, hal. 12).

\section{d. Fase Operasional}

Dalam fase ini yaitu pada usia 11 samapi dewasa pada fase ini ank sudah dapat berfikir secara abtrak, hipotesis, sistematis, mengenai sesuatu yang abtrak dalam memikirkan hal yang mungkin terjadi.

Dari tahap kognitif diatas menurut piaget bahwasanya ada empat tahap disini kita akan membahas pada tahap perkembangan anak pada anak usia dini berada pada tahap praoperasional dalam keadaan ini usia emas yang harus dioptimlkan dengan pendidikan pada anak usia dini sehingga anak akan berkembang secara optimal.

Menurut Yusuf (2006), secara umum pada usia sekolah dasar (2-7 tahuun) anak sudah dapat mereaksi rangasngan intelektual, atau melaksankaan tugas tugas belajar yang menuntut kemampuan kognitif atau kemampuan intelektual seperti menulis, membaca, dan menghitung. Pada tahap tahap ini anak usia dini harus dibekali dngan pengalaman- pengalaman dan kemampuan tertentu untuk menambah pengertian dan penanaman tingkah laku dengan pola pola agar mereka dapat menggunkan secara efektif.

Implikasi ini ditandai dengan tiga kemapuan kecakapan baru yaitu mengklasifikasikan, menyusun dan mengasosiasikan yakni mneghubungkan atau menghitung. Hal lain yang sudah dimiliki oleh anak usia dini adalah kemampuan untuk berinteraksi dengan teman sebayanya dengan baik agar ketik masuk dalam pendidikan sekolah dasar dapat optimal.

Tahapan anak usia dini juga harus dibekali oleh kecakapan berfikir dan bernalar, termasuk peberian pengetauan tentang manusia, pengetahuan tentang hewan dan alam sekitarnya karena pada tahap ini sudah mampu mengungkapkan gagasan tentang kehidupan disekitarnya karena pada tahap ini sudah mampu mengungkapkan gagasannya tentang kehidupan disekitarnya. Dalam hal ini peran orang tua dan juga peran sekolah sangat penting dalam mengembangkan kemampuan intelektual anak. Jika dihubungankan dengan teori tahap-tahap perkembangan kognitif yang diungkapkan oleh Jean Piaget anak usia dini dapat dikatakan pada tahap fase praoperasional kongkrit yaitu dimana anak sudah mulai dapat berfikir belum sepenuhnya stabil hanya saja perllu untuk dikembangkan dengan sesuai perkembanganya.

Perkembangan kognitif anak usia dini ditandai dengan hal-hal sebagai berikut:

\section{a. Tahap Prakonseptual}

Dalam tahpn ini desebut dengan pemikiran simbolik, karena pada tahap ini perkembangan anak usia dini berada pada usia 2-4 tahun maka ditandai dengan munculnya sistem simbol-simbol atau lambing (Desmita, 2009, hal. 131). Tahap ini merupakan tahapan yang paling penting dalam pencapaian tahapan 
kognitif. Melaluai pemikiran simbolois anak-anak pra sekalah dapat mengorganisir dan memproses apa yang mereka ketahui. Anak dapat dengan mudah mengingat dan membandingkan objek objek yang sudah mereka lewati.

\section{b. Tahap Intuitif}

Dalam tahap ini aktivitas anak sudah dapat mengelompokan, mengukur, atau menghubungkan namun dalam tahapn ini anak belum begitu sadar mengenai prinsip-prinsip yang melandasi terbentuknya aktiviyas tebenuk. Jadi walaupun simbol-simbol anak meningkat komplek namun penalaran dan pemikiranya masih mempunai ciri tertentu. Karakteristik lain dari pemikiran praoperasional adalah pemusatan perhatian pada satu dimensi dan mengesampingkan semua dimensi yang lain.

\section{Faktor yang Mempengaruhi Perkembangan Kognitif Anak Usia Dini}

Peserta didik usia dini senantiasa dihadapkan dengan berbagai pengalaman didalam dan diluar rumah dan juga disekolah dalam kehidupan sehari-hari. Anakanak dengan perkembngan kognitif yang sama dan melihat objek yang sama dapat memiliki prestasi yang berbeda tentang objek tersebut.

Ada beberapa faktor yang mempengaruhi perkembangan kognitif anak usia dini (Desmita, 2009, hal. 12) adalah sebagai berikut:

a. kondisi organ pengindraan sebagai saluran yang dilalui kesan indra dalam perjalannya ke otak;

b. intelegnsi dan tingkat kecerdasan:

c. kesempatan belajar yang diperoleh:

d. tipe pengalaman yang didapat secara langsung dan tidak langsung;

e. jenis kelamin dan jenis peranan yang dilatih; dan

f. kepribadian anak dalam memandang kehidupan.

Dalam perkembangan kognitif juga dapat dipengaruhi oleh kedala bahaya yang mempengaruhui perkembangan anak secara keseluruhan yaitu sebagai berikut:

a. kelambanan perkembangan otak

Hal ini dapat mempengaruhi kemampuan bermain, belajar disekolah serta kemapuan menyesuaikan diri dilingkungan sosial anak. Kelambanan ini biasanya dipengaruhi oleh faktor kurangnya pengalaman atua tingkat kecerdasan dibawah normal.

b. konsep yang keliru

Hal ini terjadi akibat imformasi yang salah, pengalaman terbatas, mudah percaya, penalaran keliru, dan imajinasi yang sangat berperan, pemikiran tidak realitas, serta salah menafsirkan arti.

Sedangkan menurut Andi Mappiare (1982) dalam (Sunarto \& Hartono, 2002, hal. 105) hal hal yang mempengaruhui perkembangan kognitif antara lain sebagai berikut :

a. Bertambahnya informasi yang disimpan didalam otak seseorang sehingga mampu berfikir reflektif; 
b. Banyaknya pengalaman-pengalaman dan menyelesaikan masalah sehingga dapat berfikir proporsional;

c. Adanya kebebasan berfikir, menimbulkan keberanian seseorang dalam menyimpulkan hipotesi hipotesis.

\section{Upaya Optimalisasi dan Simulasi terhadap Perkembangan Kognitif Anak Usia Dini}

Menurut Piaget sebagian besar anak usia dini sudah maampu memahami konsep-konsep abtrak dalam batas tertentu. Menurut Brunner siswa pada usia ini menggunakan bentuk bentuk simbol dengan cara yang makin canggih. Guru dapat membantu mereka dengan pendekatan keterampilan proses dan memberi penekatan konsep-konsep (Sunarto \& Hartono, 2002, hal. 113).

Karena siswa dalam usia ini dalam tahap proses penyempurnaan penalaran hendaknya kita jangan menganggap mereka berfikir seperti kita. Hendaknya kita harus tetap waspada dalam menginterprestasikan pendapat didalam kelas, dengan memberikan kesempatan mengungkapkan pendapat.

Dalam proses belajar mengajar juga hendaknya guru harus selalu memberikan motivasi kepada peserta didik anak usia dini, hal ini sangat penting agar mereka dapat merasa terus bersemangat untuk mengembangkan kemapuan kognitifnya.

Dengan memperhatikan tahap-tahapan perkembangan anak pada kegiatan pembelajaran dapat diwujudkan dengan kegiatan sebagai berikut.

a. Antisipasi mereka untuk duduk selama bercerita, kesempatan untuk bergerak.

b. Berilah tugas, seperti mengulang hapalan, atau cerita;

c. Beri tanggunng jawab sesuai kemampuan;

d. Berilah ceita Al-quran atau Nabi-nabi terdahulu;

e. Pakailah alat peraga dengan huruf yang jelas;

f. Pakai lah kata kata dan contoh contoh yang kongkrit dan sederhana ;

g. Janganlah banyak menawarkan keputusan;

h. Berilah contoh yang baik dalam kelakuan dan perkataan.

Hal ini sesuai dengan teori yang dikemukakan oleh Piaget bahwasanya anak usia diniadalah tahap praopersiaonal anak usia dini akan sulit memahami pelajaran dan harus menggunakan hal hal yang kogkrit misalnya dengan membawa alat peraga atau media.

\section{SIMPULAN}

Perkembanngan kognitif adalah salah satu aspek perkembangan peserta didik yang berkaitan dengan pengetahuan yaitu proses psikologis yang berkaitan yaitu bagaimana individu untuk mempelajari lingkunganya. Mengembangkan kognitif peserta didik adalah merupakan tugas seorang guru yang harus diterapkan dalam proses pembelajaran. 
Tahap-taap pemikiran dari seorang menurut jean piaget berkembang melalui serangkian pemikiran dari masa bayi hingga masa dewasa yaitu fase sensiromotor, fase praoperasional, fase oprasi kongkrit, dan fase formal.

Ada bebrapa faktor yang mempengaruhi perkembangan kognitif anak usia dini diantaranya adalah a) kondisi organ pengindraan sbagai saluran yang dilalui kesan indra dalam perjalanannya ke otak; b) integensi dan tingkat kecerdasannya; c) kesempatan belajar yang diperoleh; d) tipe pengalaman anak yang didepa secara langsung dan tidak langsung; e) jenis kelamin, dan dan jenis peranan yang dilatih; dan $\mathrm{f}$ ) kepribdian anak dalam memandang kehidupan.

Karena siswa dalam usia ini dalam tahap proses penyempurnaan penalaran hendaknya kita jangan menganggap mereka berfikir seperti kita. Hendaknya kita harus tetap waspada dalam menginterprestasikan pendapat didalam kelas, dengan memberikan kesempatan mengungkapkan pendapat.

\section{DAFTAR PUSTAKA}

Baharuddinn, \& Wahyuni, N. (2010). Teori Belajar dan Pembelajaran. Yogyakarta: Ar-Ruzz Media.

Desmita. (2009). Perkembangan Peserta Didik. Batu Sangkar: PT. Remaja Rosda Karya.

Hasan, P. (2006). Psikologi Perkembangan Islam. Jakarta: PT. Raja Grafindo Persada.

Indonesia, R. (2014). Peraturan Menteri Pendidikan dan Kebudayaan Republik Indonesia Nomor 137 Tahun 2014 Tentang Standar Nasional Pendidikan Anak Usia Dini. Jakarta: Kemendikbud RI.

Khadijah. (2016). Perkembangan Kognitif Anak Usia Dini. Medan: Perdana Publishing. Patmonodewo, S. (2003). Pendidikan Anak Prasekolah. Jakarta: Rineka.

Sit, M. (2015). Psikologi Perkembangan Anak Usia Dini. Medan: Perdana Publishing.

Sit., M. (2012). Perkembangan Peserta Didik. Medan: Perdana Publishing.

Sujiono, Y. N. (2013). Konsep Dasar Pendidikan Anak Usia Dini. Jakarta: PT. Indek.

Sunarto, \& Hartono, B. A. (2002). Perkembangan Peserta Didik. Jakarta: PT. Rineka Cipta.

Yusuf, S. (2012). Psikologi Perkembangan Islam. Jakarta: PT. Remaja Rosdakarya. 